\title{
Pengaruh 7-Step Problem Based Learning terhadap Kemampuan Pemecahan Masalah ditinjau dari Kemampuan Bernalar Ilmiah
}

\author{
Amin Mustajab $^{1}$, Muhardjito $^{1}$, Sunaryono $^{1}$ \\ ${ }^{1}$ Pendidikan Fisika-Universitas Negeri Malang
}

\begin{tabular}{l} 
INFO ARTIKEL \\
\hline Riwayat Artikel: \\
Diterima: 23-05-2019 \\
Disetujui: $13-03-2020$ \\
\hline
\end{tabular}

\section{Kata kunci:}

problem based learning; problem solving skill; scientific reasoning skills; problem based learning; kemampuan pemecahan masalah; kemampuan bernalar ilmiah

\author{
Alamat Korespondensi: \\ Amin Mustajab \\ Pendidikan Fisika \\ Universitas Negeri Malang \\ Jalan Semarang 5 Malang \\ E-mail: aminmustajab53@gmail.com
}

\begin{abstract}
ABSTRAK
Abstract: The purpose of this study to determine how the differences students' problem solving abilities between 7-step PBL and conventional methods are reviewed from scientific reasoning ability. Total sample in this study (N) 125 students selected using the convienence sampling technique. The method used in this study is a quantitative research method with factorial $2 \times 2$ research design. Results of the study show that the learning method provides statistical difference in students' problem solving abilities. The average value of problem solving abilities of students who take part in learning using the PBL 7-step method is 60.51. In the conventional class is 51.12.

Abstrak: Penelitian ini bertujuan mengetahui bagaimana perbedaan kemampuan pemecahan masalah siswa antara metode 7-step PBL dan konvensional ditinjau dai kemampuan bernala ilmiah. Sampel pada penelitian ini (N) berjumlah 125 siswa yang dipilih menggunakan teknik convienence sampling. Metode yang digunakan dalam penelitian ini merupakan metode penelitian kuantitatif dengan desain penelitian factorial $2 \times 2$. Terdapat perbedaan secara statistik antara metode 7-step PBL dan konvensional terhadap kemampuan pemecahan masalah siswa. Rerata nilai kemampuan pemecahan masalah ikuti siswa untuk belajaran dengan menggunakan metode 7-step $P B L$ sebesar 60,51. Pada kelas konvensional rerata nilai kemampuan pemecahan masalah siswa sebesar 51,12.
\end{abstract}

Membantu siswa mengembangkan keterampilan memecahkan masalah (bukan untuk mengumpulkan informasi) merupakan salah satu tujuan pendidikan fisika (Rees, Pardo, \& Parker, 2013). Pemecahan masalah telah lama menjadi fokus penelitian pendidikan fisika karena pemecahan masalah merupakan ranah kognitif yang mencakup seluruh domain konten (Harks, Klieme, Hartig, \& Leiss, 2014). Pemecahan masalah melibatkan proses peningkatan dan adaptasi yang berkelanjutan dalam menghadapi tantangan yang kompleks sehingga menghasilkan pembelajaran yang mendalam (Harnett, 2012). Penggunaan tugas pemecahan masalah juga memberikan kesempatan bagi siswa untuk memodifikasi atau mengganti pengetahuan sebelumnya dengan konsep ilmiah agar berhasil menjawab masalah yang dihadapi siswa (Loyens, Jone Mikkers, \& van Gog, 2015). Konsep-konsep ilmiah tidak muncul begitu saja, tetapi dielaborasikan dalam proses pemecahan masalah yang melibatkan penerapan berbagai macam prosedur. Proses ini disebut sebagai proses penalaran ilmiah (Magnani, 2002). Temuan dari Wuriyudani et al. (2018) menunjukan bahwa kemampuan pemecahan masalah memberikan pengaruh terhadap kemampuan bernalar ilmiah siswa.

Seiring peningkatan beban kognitif selama proses pembelajaran, siswa sering kesulitan menemukan solusi untuk memecahkan masalah (Smart \& Marshall, 2013). Bahkan siswa yang belajar fisika di tingkat perguruan tinggi sering mengalami kesulitan dalam menyelesaikan masalah meskipun fakta bahwa pemecahan masalah adalah bagian integral dari sebagian besar kelas fisika (Tuminaro \& Redish, 2007). Kesulitan siswa mengatasi masalah dapat diatasi jika beban kerja pemecahan masalah dibagi (Kuhn \& Pease, 2008). Selain itu, temuan dari Mason and Singh (2016) menunjukan bahwa dengan mengkategorikan konsep-konsep fisika pada tugas yang diberikan membantu siswa dalam memecahkan masalah. Pengakategorian dan penataan diskusi memungkinkan siswa untuk mengkategorikan masalah berdasarkan konsep fisika yang mendasari masalah. 
Pembelajaran berbasis masalah umumnya diimplementasikan sebagai tutorial kelompok kecil di mana siswa belajar melalui skenario pembelajaran. Skenario melibatkan masalah yang menjadi lebih kompleks dari waktu ke waktu (Jaffe, Gibson, \& D’Amico, 2015), menarik, terbuka, dan nyata untuk memotivasi siswa (Sahin, 2010). Problem Based Learning dapat meningkatkan prestasi akademik, kemampuan kognitif serta keterampilan prosedural (Baran \& Sozbilir, 2018) dan kemampuan argumentasi ilmiah (Pritasari, Dwiastuti, \& Probosari, 2016).

\section{Kemampuan Pemecahan Masalah}

Terdapat empat komponen utama rubrik pemecahan masalah terstruktur, representasi masalah, mengembangkan solusi, pembenaran solusi, dan mengevaluasi solusi. Representasi masalah dibentuk dengan dua sub-komponen; mengidentifikasi penyebab masalah dan mengidentifikasi informasi yang relevan. Mengembangkan solusi dibentuk dengan dua sub-komponen; mengusulkan atau mengembangkan solusi dan kualitas solusi. Akhirnya, pembenaran solusi juga dibentuk dengan dua subkomponen; membangun argumen, dan memberikan bukti (Demiraslan Çevik, 2015).

Tabel 1. Rubrik Kemampuan Pemecahan Masalah

\begin{tabular}{|c|c|c|c|c|}
\hline \multirow[t]{2}{*}{ Level } & \multicolumn{4}{|c|}{ Langkah Pemecahan Masalah } \\
\hline & $\begin{array}{l}\text { Mendefinisikan dan } \\
\text { memahami masalah }\end{array}$ & $\begin{array}{l}\text { Menyusun rencana atau } \\
\text { strategi untuk } \\
\text { menyelesaikan masalah }\end{array}$ & $\begin{array}{c}\text { Melaksanakan rencana } \\
\text { tersebut }\end{array}$ & $\begin{array}{c}\text { Merefleksikan } \\
\text { (mengevaluasi) solusi }\end{array}$ \\
\hline 1 & $\begin{array}{l}\text { Menunjukkan pemahaman } \\
\text { terbatas tentang masalah } \\
\text { dan konteks yang lebih luas. }\end{array}$ & $\begin{array}{l}\text { Siswa tidak memiliki } \\
\text { kemampuan untuk } \\
\text { mempertimbangkan strategi } \\
\text { baru walaupun strategi yang } \\
\text { digunakan jelas tidak tepat }\end{array}$ & $\begin{array}{l}\text { Menyatakan paling banyak satu, } \\
\text { seringkali. Siswa tidak } \\
\text { mengenali banyak cara untuk } \\
\text { menjalankan rencana meskipun } \\
\text { solusi tampak salah }\end{array}$ & $\begin{array}{l}\text { Siswa tidak menganalisis atau } \\
\text { mensintesis hasil }\end{array}$ \\
\hline 2 & $\begin{array}{l}\text { Menunjukkan pemahaman } \\
\text { yang dikembangkan } \\
\text { sebagian dari masalah dan } \\
\text { mengidentifikasi beberapa } \\
\text { faktor spesifik yang } \\
\text { memengaruhi pendekatan } \\
\text { terhadap masalah sebelum } \\
\text { menyelesaikannya }\end{array}$ & $\begin{array}{l}\text { Siswa jarang mengenali } \\
\text { perlunya beberapa solusi, } \\
\text { tetapi terkadang dapat } \\
\text { melakukannya ketika diminta } \\
\text { atau ketika menghapus solusi } \\
\text { yang tidak tepat. }\end{array}$ & $\begin{array}{l}\text { Terkadang siswa menyadari } \\
\text { perlunya beberapa langkah untuk } \\
\text { melaksanakan rencana tersebut } \\
\text { terutama jika upaya pertama } \\
\text { gagal tetapi siswa melakukannya } \\
\text { dengan kemampuan terbatas. }\end{array}$ & $\begin{array}{l}\text { Siswa terkadang menerapkan } \\
\text { pengetahuan latar belakang } \\
\text { atau konteks masalah ketika } \\
\text { mempertimbangkan solusi. }\end{array}$ \\
\hline 3 & $\begin{array}{l}\text { Menunjukkan pemahaman } \\
\text { yang jelas tentang masalah } \\
\text { dan mengidentifikasi } \\
\text { banyak faktor spesifik yang } \\
\text { memengaruhi pendekatan } \\
\text { terhadap masalah sebelum } \\
\text { menyelesaikannya }\end{array}$ & $\begin{array}{l}\text { Siswa akan dapat } \\
\text { mengoordinasikan dua proses } \\
\text { menjadi strategi dan } \\
\text { mengartikulasikan komponen } \\
\text { penting dari strategi Siswa. }\end{array}$ & $\begin{array}{l}\text { Siswa dapat } \\
\text { mengimplementasikan rencana } \\
\text { dengan jumlah proses atau } \\
\text { langkah yang terbatas dan } \\
\text { menyatakan satu atau lebih solusi } \\
\text { potensial yang akurat }\end{array}$ & $\begin{array}{l}\text { Siswa sering menerapkan } \\
\text { pengetahuan latar belakang } \\
\text { atau konteks masalah ketika } \\
\text { mempertimbangkan solusi. } \\
\text { Solusi yang salah mengarah } \\
\text { kerefleksi dan penyesuaian } \\
\text { dalam perencanaan. }\end{array}$ \\
\hline 4 & $\begin{array}{l}\text { Menunjukkan pemahaman } \\
\text { yang jelas tentang masalah } \\
\text { dan mengidentifikasi faktor- } \\
\text { faktor spesifik yang } \\
\text { memengaruhi pendekatan } \\
\text { masalah sebelum } \\
\text { menyelesaikannya }\end{array}$ & $\begin{array}{l}\text { Siswa akan menunjukkan } \\
\text { kemampuan untuk } \\
\text { membalikkan suatu proses } \\
\text { guna membentuk rencana dan } \\
\text { dengan jelas } \\
\text { mengartikulasikan proses } \\
\text { pengambilan keputusan } \\
\text { (dalam kata-kata atau rumus } \\
\text { aljabar) }\end{array}$ & $\begin{array}{l}\text { Siswa dapat } \\
\text { mengimplementasikan rencana } \\
\text { dengan beberapa proses atau } \\
\text { langkah (termasuk proses } \\
\text { terbalik) dan mengidentifikasi } \\
\text { secara akurat setidaknya satu } \\
\text { solusi yang tepat atau dapat } \\
\text { diterapkan (sering kreatif) }\end{array}$ & $\begin{array}{l}\text { Siswa selalu dapat menerapkan } \\
\text { pengetahuan latar belakang } \\
\text { atau konteks masalah ketika } \\
\text { mempertimbangkan solusi. } \\
\text { Siswa dapat merenungkan } \\
\text { solusi untuk melakukan } \\
\text { penyesuaian dan memberikan } \\
\text { wawasan tentang rencana siswa }\end{array}$ \\
\hline
\end{tabular}

Empat langkah pemecahan masalah menurut Polya (1973) terdiri dari langkah mendefinisiskan dan memahami masalah, menyusun rencana untuk menyelesaikan masalah, melaksanakan rencana dan mengevaluasi solusi. Rubrik kemampuan pemecahan masalah berdasarkan langkah pemecahan masalah milik Polya (Hostos Community College, 2017) disajikan pada tabel 1 .

Hasil penelitian dari Mustofa \& Rusdiana (2016) menunjukan bahwa kemampuan pemecahan masalah siswa masih berada pada kategori cukup. Temuan dari Sujarwanto \& Hidayat (2014) menunjukan bahwa siswa masih kesulitan dalam memahami dan mengidentifikasi masalah, merencanakan strategi, melaksanakan strategi serta solusi di evaluasi. Pada langkah mengidentifikasi dan memahami masalah siswa hanya mengelompokan masalah berdasarkan apa yang diketahui dan ditanyakan pada masalah. Pada tahap merencanakan strategi, siswa membuat diagram bebas tanpa membuat makna fisi dan terdapat siswa yang tidak dapat menentukan persaaan dengan benar. Pada tahap melaksanakan strategi sebagian besar siswa yang gagal dalam strategi implementasi disebabkan oleh kecerobohan selama perhitungan (Alias \& Ibrahim, 2015). Pada tahap mengevaluasi 
solusi siswa hanya mengevaluasi berdasarkan fakta yang diketahui dan yang ditanyakan pada dalam masalah serta masih terdapat siswa yang salah menuliskan satuan (Sujarwanto \& Hidayat, 2014).

\section{Kemampuan Penalaran Ilmiah}

Tytler \& Peterson (2005) mengidentifikasi tiga level kemampuan penalaran ilmiah. Level satu, tidak melibatkan pengamatan sistematis atau perbandingan tetapi penjelasan didorong oleh titik data tunggal. Level dua, terlibat membuat kesimpulan tentang hubungan antara variabel atau ide teoritis yang didorong oleh data dengan beberapa interpretasi konseptual. Level tiga, melibatkan hubungan antara variabel menggunakan teori. Brown, Furtak, Timms, Nagashima, \& Wilson (2010) membagi tiga level kemampuan penalaran ilmiah. Level satu, tidak mengetahui dipercobaan. Level dua, mengetahui tujuan dari kegiatan eksperimen, bahwa eksperimen memiliki tujuan menguji ide untuk melihat apakah itu benar. Level tiga, tidak hanya memiliki perbedaan antara level satu dan level dua tetapi juga menghargai hubungan antara hasil eksperimen dan ide yang diuji (Wu \& Tsai, 2011).

Salah satu instrumen yang digunakan untuk mengukur bernalar ilmiah adalah Classroom Test Scientific Reasoning (CTSR). Classroom Test Scientific Reasoning mengukur penalaran proporsional siswa, penalaran probabilistik, variabel pengendali, penalaran korelasional, dan kemampuan hypodeductive reasoning (Lawson, 2000). Tes ini terdiri dari 12 ganda beralasan. Siswa harus menjawab kedua tingkat dengan benar untuk menerima satu poin, sehingga skor tertinggi dapat menjadi 12. Lee \& She (2010) membagi kemampuan bernalar ilmiah siswa menjadi empat tingkat. Skor kemampuan bernalar ilmiah siswa $0-2$ diklasifikasikan berada pada tingkat operasional pra-konkret Piaget. Skor 3-4 diklasifikasikan pada tingkat operasional pasca-konkret Piaget. tingkat transisional diklasifikasikan sebagai skor 5-8 dan skor siswa diklasifikasikan sebagai tingkat operasional formal Piaget yang memiliki dari 9-12.

Temuan dari Jensen, Neeley, Hatch, \& Piorczynski (2017) menunjukan bahwa terdapat korelasi antara kemampuan bernalar ilmiah dan prestasi dalam pembelajaran. Hasil penelitian Alshamali \& Daher (2016) menunjukkan bahwa tingkat penalaran ilmiah yang tinggi memberikan hasil kemampuan pemecahan masalah yang tinggi pada guru-guru sains. Secara khusus, siswa yang memahami konsep teoritis menunjukkan tingkat penalaran ilmiah yang lebih tinggi daripada mereka yang hanya menguasai konsep hipotetis. Demikian pula, mereka yang hanya memiliki konsep deskriptif menunjukkan keterampilan penalaran terendah (Ding, Wei, \& Liu, 2016)

\section{Problem Based Learning}

Pembelajaran berbasis masalah $(P B L)$ dapat dianggap sebagai pendekatan konstruktivis (Askell-Williams, MurrayHarvey, \& Lawson, 2007; Hung, 2016; Ulger, 2018) untuk pendidikan (Yew \& Schmidt, 2012). Pembelajaran berbasis masalah adalah strategi pengajaran dan pembelajaran yang digunakan untuk melibatkan siswa dalam memecahkan masalah. Problem Based Learning didefinisikan sebagai pedagogi yang berfokus pada siswa (Raine \& Symons, 2012; Senocak, Taskesenligil, \& Sozbilir, 2007; Tosun \& Senocak, 2013) di mana siswa mengembangkan kemandirian intelektual ketika bekerja melalui masalah dengan sedikit arahan dari guru (Vandenhouten, Groessl, \& Levintova, 2017).

Problem Based Learning dapat meningkatkan prestasi akademik, kemampuan kognitif, keterampilan prosedural (Baran \& Sozbilir, 2017) kemampuan argumentasi ilmiah (Pritasari et al., 2016) serta memungkinkan siswa untuk bekerja dalam kelompok secara kooperatif dan membangun pengetahuan melalui negosiasi sosial dibandingkan dengan metode pengajaran tradisional (Akçay, 2009; Cross, Taasoobshirazi, Hendricks, \& Hickey, 2008). Yew, Chng, \& Schmidt (2011) menunjukkan bahwa tiga fase PBL: analisis masalah, belajar mandiri, dan fase pelaporan, memainkan peran khusus dalam memengaruhi kemampuan benalaran alamiah siswa. Martin \& Hand (2009) melaporkan kemajuan dalam pemahaman konsep ketika siswa diberi kesempatan untuk bekerja secara kolaboratif untuk memecahkan masalah dan mendiskusikan pandangan alternatif. Temuan dari Loyens et al., (2015) bahwa $P B L$ dapat meningkatkan perubahan konseptual karena siswa mempertimbangkan dengan serius dan kritis terhadap informasi yang kontras antara penjelasan ilmiah dan miskonsepsi sebelumnya.

Guru sebagai pendidik perlu mempertimbangkan berbagai metode pembelajaran guna mengatasi kesulitan siswa dalam memecahkan masalah, metode pembelajaran berbasis masalah merupakan salah satu metode pembelajaran yang dapat digunakan. Disisi lain, kemampuan bernalar ilmiah dapat memengaruhi prestasi belajar siswa, bahkan pada guru sain yang memiliki kemampuan bernalar ilmiah tinggi juga memiliki kemampuan pemecahan yang tinggi. Maka pada penelitian ini, peneliti ingin melihat bagaiamana 7-step PBL dan kemampuan bernalar ilmiah memengaruhi kemampuan pemecahn masalah.

\section{METODE}

Metode yang digunakan dalam penelitian ini merupakan metode penelitian kuantitatif dengan desain penelitian factorial $2 \times 2$. Data kemampuan pemecahan masalah dianalisis menggunakan uji statistik two-way anova. Populasi pada penelitian ini adalah seluruh siswa kelas X SMA Negeri 4 Malang. Teknik pemilihan sampel yang digunakan adalah convenience sampling. Sampel dalam penelitian ini menggunakan 4 kelas X SMA Negeri 4 Malang yang berjumlah 125 siswa.

Kemampuan pemecahan masalah siswa diukur menggunakan empat butir soal uraian yang sudah diuji validitas dan reliabilitasnya. Soal kemampuan pemecahan masalah diberikan setelah pembelajaran dilakukan baik pada kelas dengan metode 7-step PBL dan metode konvensional. Tingkat kemampuan bernalar ilmiah siswa pada kelas pembelajaran dengan 
menggunakan metode 7-step PBL dan kelas pembelajaran dengan menggunakan metode konvensional diukur menggunakan soal kemampuan bernalar ilmiah milik Lawson (2000). Dari 12 soal kemampuan bernalar ilmiah milik Lawson (2000) hanya digunakan 11 butir soal karena 11 soal yang digunakan sudah mencakup keseluruhan indikator yang terdapat pada soal kemampuan bernalar ilmiah. Tes untuk mengukur kemampuan bernalar ilmiah dilakukan sebelum pembelajaran.

\section{HASIL}

Hasil uji statistik menunjukan bahwa tidak dapat perbedaan untuk pemecahan masalah antara siswa yang memiliki kemampuan bernalar ilmiah tinggi dan rendah. Sementara metode pembelajaran menunjukan perbedaan kemampuan pemecahan masalah antara kelas yang meneggunakan metode 7-step PBL dan konvensional. Secara bersama-sama, kemampuan bernalar ilmiah dan metode pembelajaran tidak memberikan perbedaan kemampuan pemecahan masalah.

Hasil pemecahan masalah dilihat dari langkah pemecahan masalah antara kelas 7-step pembelajaran berbasis masalah dan konvensional disajikan pada gambar 1. Pada komponen mendefinisikan dan memahami masalah, rerata nilai siswa pada pemahaman pecahan masalah sebesar 69,76 untuk kelas dengan metode pembelajaran 7-step PBL sementara pada kelas konvensional rerata nilai pemecahan masalah siswa sebesar 64,38. Pada komponen menyusun rencana atau strategi, rerata nilai pecahan masalah siswa sebesar 59,17 di kelas dengan menggunakan metode 7-step PBL sementara di kelas konvensional rerata nilai kemampuan pemecahan masalah siswa sebesar 50,30. Pada komponen melaksanakan rencana, rerata nilai kemampuan pemecahan masalah siswa sebesar 59,78 pada kelas 7-step PBL sementara di kelas konvensional rerata kemampuan pemecahan masalah siswa sebesar 47,32. Pada komponen merefleksikan (mengevaluasi) solusi rerata nilai kemampuan pemecahan masalah siswa pada kelas dengan menggunakan metode 7-step PBL sebesar 53,33 sementara pada kelas konvensional rerata nilai kemampuan pemecahan masalah siswa sebesar 45,14 .

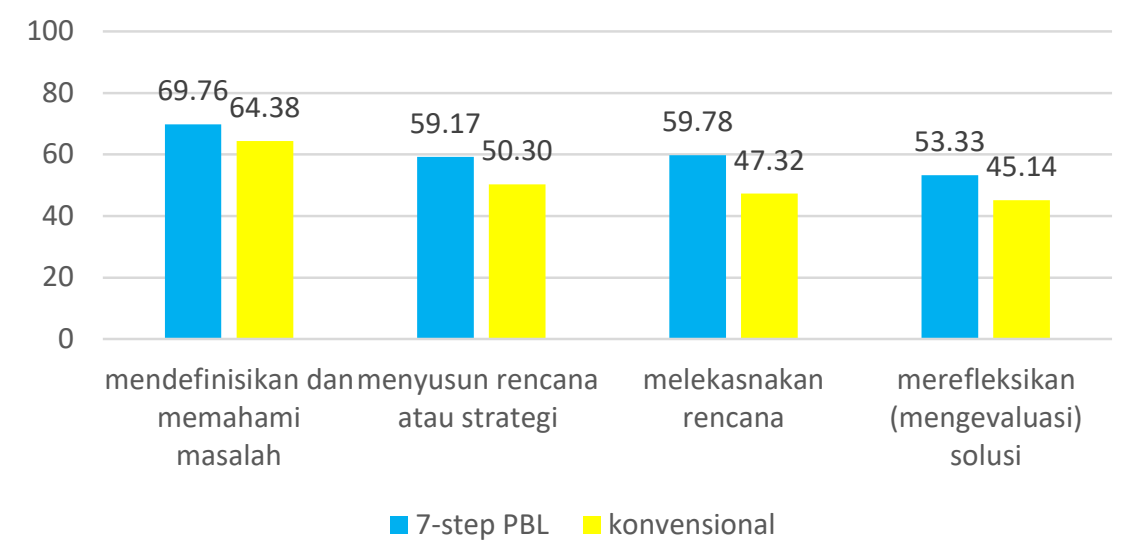

\section{Gambar 1. Rerata nilai kemampuan pemecahan masalah pada tiap langkah pemecahan masalah kelas dilihat dari metode pembelajaran}

Hasil kemampuan pemecahan masalah dilihat dari metode pembelajaran disajikan pada gambar 2. Rerata nilai kemampuan pemecahan masalah ditahap mendefinisikan dan memahami masalah pada siswa dengan dengan kemampuan bernalar lmiah rendah sebesar 64,65, sementara pada siswa dengan kemampuan bernalar ilmiah tinggi sebesar 68,46. Rerata nilai kemampuan pemecahan masalah di tahap menyusun rencana atau strategi pada siswa dengan kemampun bernalar ilmiah rendah sebesar 51,84, sementara pada siswa dengan kemampuan bernalar ilmiah tinggi sebesar 56,05. Rerata nilai kemampuan pemecahan masalah di tahap melaksanakan rencana pada siswa dengan kemampuan bernalar ilmiah rendah sebesar 51,95, sementara siswa dengan kemampuan bernalar ilmiah tinggi sebesar 54,69. Rerata kemampuan pemecahan masalah pada tahap merefleksikan (mengevaluasi) solusi pada siswa dengan kemampuan bernalar ilmiah rendah sebesar 48,05, sementara siswa dengan kemampuan bernalar ilmiah tinggi sebesar 50,20. 


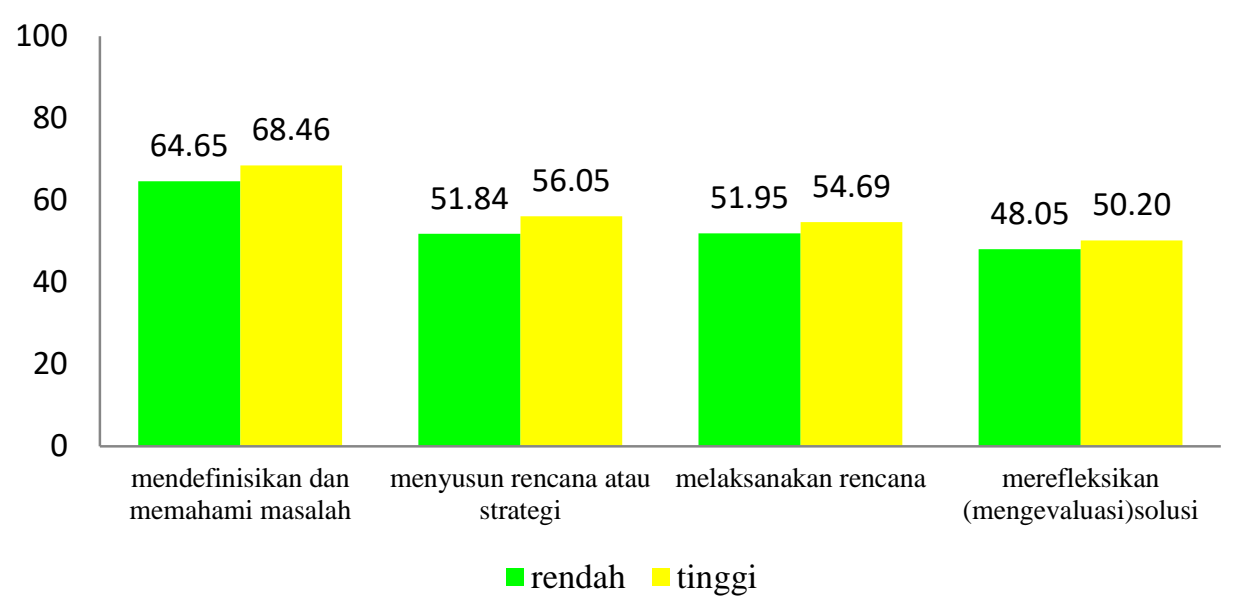

\section{Gambar 2. Rerata nilai kemampuan pemecahan masalah pada tiap komponen pemecahan masalah dilihat dari kemampuan bernalar ilmiah}

Rerata kemampuan pemecahan masalah siswa setelah mengikuti pembelajaran dengan metode 7-step PBL disajikan pada gambar 3. Sebanyak 30,56\% siswa berada pada level 1. Sebanyak 40,32\% siswa berada pada level 2. Sebanyak $29,03 \%$ siswa berada pada level 3. Rerata kemampuan pemecahan masalah siswa setelah mengikuti pembelajaran pada kelas dengan metode konvensional disajikan pada Gbr. 4. Sebanyak 51,61\% siswa berada pada level 1. Pada level 2 terdapat sebanyak 40,32\% siswa. Sebanyak 9,67\% siswa berada pada level 3.

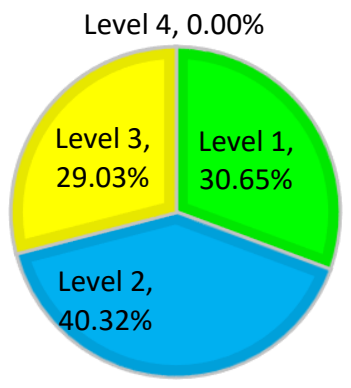

Gambar 4. Rerata kemampuan pemecahan masalah pada kelas 7-step PBL

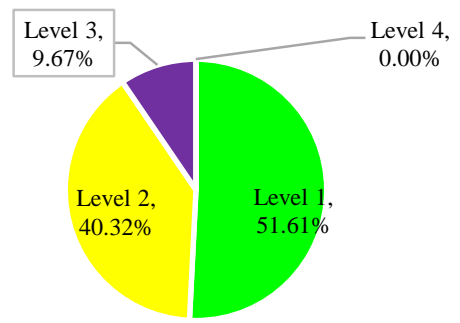

Gambar 4. Rerata kemampuan pemecahan masalah pada kelas konvensional

\section{PEMBAHASAN}

Dari gambar 2 nilai rerata kemampuan pemecahan masalah siswa yang memiliki kemampuan bernalar ilmiah tinggi lebih tinggi dibandingkan dengan siswa yang memiliki kemampuan bernalar ilmiah rendah pada keempat langkah pemecahan masalah. Hal ini di sebabkan oleh beberapa hal, pada tahap mendefinisikan dan memahami masalah siswa yang memiliki kemampuan bernalar ilmiah rendah memiliki pemahaman yang terbatas terkait dengan masalah hal ini sejalan dengan temuan 
Rimadani, Parno, \& Diantoro (2017) kebanyakan siswa menjawab soal hanya meneruskan informasi yang diterima tanpa menggali lebih dalam permasalahan yang diberikan, selain itu pada tahap merencanakan solusi siswa gagal mempertimbangkan strategi baru ketika strategi yang digunakan tidak tepat hal ini sesuai dengan temuan Sambada (2012) siswa kurang mempertimbangan alternatif jawaban sehingga strategi pemecahan masalah tidak terperinci, selain itu kemampuan pada tahap sebelumnya akan mempengaruhi tahap berikutnya hal ini sejalan dengan temuan Mustofa \& Rusdiana (2016) ketika siswa siswa mengalami kesulitan dalam memahami masalah siswa juga akan kesulitan pada tahap merencanakan solusi. Pada tahap melaksanakan rencana siswa a tidak mengenali banyak jalur untuk menjalankan rencana meskipun solusi tampak salah hal ini sesuai dengan temuan Fathiah, Kaniawati, \& Utari (2015) siswa belum mampu menerapkan persamaan memecahkan masalah fisika terkait dengan materi fluida dinamis. Pada tahap mengevaluasi solusi siswa mengidentifikasi solusi yang sebagian benar dengan beberapa alasan dengan kemampuan terbatas untuk memeriksa solusi yang diberikan.

Dari hasil uji statistik two-way anova terdapat perbedaan kemampuan pemecahan masalah antara siswa yang mengikuti pembelajaran dengan menggunakan metode 7-step PBL dan konvensional. Hal ini disebabkan oleh beberapa hal, pertama pembelajaran 7-step $P B L$ pada langkah klarifikasi istilah dan konsep memberikan kesempatan kepada guru untuk mengintervensi jika siswa memberikan penjelasan yang salah untuk kata/konsep dari masalah yang diberikan sehingga siswa pada kelas pembelajaran dengan menggunakan metode 7-step PBL menunjukkan penjelasan dan pemahaman yang unggul dibandingkan dengan siswa pada kelas konvensional. Hasil sejalan dengan temuan (Yew \& Schmidt, 2012) salah satu kelebihan PBL dibandingkan pengajaran berbasis ceramah tradisional terletak pada kemampuannya untuk membantu siswa mengintegrasikan konsep baru dengan pengetahuan yang ada.

Kesalahpahaman siswa dalam mengintegrasikan pengetahuan sebelumnya dan masalah yang diberikan dapat diatasi pada langkah pembelajaran merumuskan pernyataan dari masalah, siswa diberi kesempatan menetapkan masalah yang disepakati tidak hanya menyebutkannya tetapi mendiskusikan rumusan masalah dan juga memeriksa relevansi yang lebih luas, hal ini sejalan dengan temuan (Loyens, Jones, Mikkers, \& Gog, 2015) penggunaan tugas pemecahan masalah memberikan kesempatan bagi siswa untuk memodifikasi atau mengganti pengetahuan mereka sebelumnya dengan sudut pandang ilmiah agar berhasil menjawab pertanyaan-pertanyaan yang diajukan.

Pada langkah belajar mandiri di pembelajaran 7-step PBL, siswa diperintahkan untuk memilih sumber belajar untuk mengatasi masalah pembelajaran yang dirumuskan dalam kelompok diskusi kecil mereka. Hal ini membuat siswa berperan secara aktif dalam proses pembelajaran, tidak hanya menerima materi pembelajaran seperti pada kelas konvensional. Hal ini sejalan dengan hasil penelitian (Wijnia, Loyens, Derous, \& Schmidt, 2015)bahwa PBL menawarkan siswa lebih banyak tanggung jawab selama proses pembelajaran dengan membiarkan siswa memilih literatur untuk belajar dari beberapa literature yang telah ditentukan dapat meningkatkan persepsi mereka tentang menjadi pelajar yang mandiri.

Hal lain yang mengakibatkan terdapatnya perbedaan kemampuan pemecahan masalah antara siswa yang mengikuti pembelajaran dengan metode 7-step PBL dan konvensional adalah kemampuan menerapkan pengetahuan yang diperoleh selama pembelajaran terhadap situasi/permasalahan yang baru. Hal ini sejalan dengan temuan (Yadav, Subedi, Lundeberg, \& Bunting, 2011) siswa PBL lebih mengingat tentang penerapan prinsip. Secara khusus, hasil penelitian menunjukkan bahwa siswa setidaknya dua kali lebih baik pada topik yang diajarkan melalui pembelajaran berbasis masalah dibandingkan dengan siswa yang diajarkan melalui metode ceramah tradisional, siswa lebih mampu memecahkan masalah dan mentransfer pembelajaran ke situasi baru.

\section{SIMPULAN}

Dari hasil penelitian dan pembahasan dapat disimpulkan beberapa hal. Pertama, terdapat perbedaan rerata kemampuan pemecahan masalah secara statistik antara siswa yang mengikuti pembelajaran menggunakan metode 7-step PBL dan konvensional. Hal ini ditunjukan oleh rerata nilai kemampuan pemecahan masalah siswa yang mengikuti pembelajaran dengan menggunakan metode 7-step PBL sebesar 60,51. Pada kelas konvensional rerata nilai kemampuan pemecahan masalah siswa sebesar 51,12. Kedua, tidak terdapat perbedaan kemampuan pemecahan masalah statistik antara siswa yang memiliki kemampuan bernalar ilmiah tinggi dan rendah. Ketiga, secara bersama-sama kemampuan bernalar ilmiah dan metode pembelajaran tidak memberikan perbedaan secara statistik. Penelitian ini belum melihat perbedaan peningkatan kemampuan pemecahan masalah antara siswa yang mengikuti kelas dengan menggunakan metode 7-step PBL dan konvensional, sehingga diharapkan kedepanya perlu dilihat perbedaan peningkatan kemampuan pemecahan masalah antara siswa yang mengikuti kelas dengan menggunakan metode 7-step PBL dan konvensional. 


\section{DAFTAR RUJUKAN}

Akçay, B. (2009). Problem-Based Learning in Science Education. Journal of Turkish Science Education, 6(1), 26-36. https://doi.org/10.1016/j.sbspro.2015.08.157

Alias, S. N. B., \& Ibrahim, F. B. (2015). Problem Solving Strategy in Balanced Forces. International Journal of Business and Social Science, 6(8), 5.

Alshamali, M. A., \& Daher, W. M. (2016). Scientific Reasoning and Its Relationship with Problem Solving: The Case of Upper Primary Science Teachers. International Journal of Science and Mathematics Education, 14(6), 1003-1019. https://doi.org/10.1007/s10763-015-9646-1

Askell-Williams, H., Murray-Harvey, R., \& Lawson, M. J. (2007). Teacher Education Students' Reflections on How ProblemBased Learning has Changed their Mental Models about Teaching and Learning. The Teacher Educator, 42(4), 237263. https://doi.org/10.1080/08878730709555406

Baran, M., \& Sozbilir, M. (2017). An Application of Context- and Problem-Based Learning (C-PBL) into Teaching Thermodynamics. Research in Science Education, 1-27. https://doi.org/10.1007/s11165-016-9583-1

Baran, M., \& Sozbilir, M. (2018). An Application of Context- and Problem-Based Learning (C-PBL) into Teaching Thermodynamics. Research in Science Education, 48(4), 663-689. https://doi.org/10.1007/s11165-016-9583-1

Brown, N. J. S., Furtak, E. M., Timms, M., Nagashima, S. O., \& Wilson, M. (2010). The Evidence-Based Reasoning Framework: Assessing Scientific Reasoning. Educational Assessment, 15(3-4), 123-141. https://doi.org/10.1080/10627197.2010.530551

Cross, D., Taasoobshirazi, G., Hendricks, S., \& Hickey, D. T. (2008). Argumentation: A Strategy for Improving Achievement and Revealing Scientific Identities. International Journal of Science Education, 30(6), 837-861. https://doi.org/10.1080/09500690701411567

Demiraslan Çevik, Y. (2015). Assessor or assessee? Investigating the differential effects of online peer assessment roles in the development of students' problem-solving skills. Computers in Human Behavior, 52, 250-258. https://doi.org/10.1016/j.chb.2015.05.056

Ding, L., Wei, X., \& Liu, X. (2016). Variations in University Students' Scientific Reasoning Skills Across Majors, Years, and Types of Institutions. Research in Science Education, 46(5), 613-632. https://doi.org/10.1007/s11165-015-9473-y

Fathiah, Kaniawati, I., \& Utari, S. (2015). Analisis Didaktik Pembelajaran yang Dapat Meningkatkan Korelasi antara Pemahaman Konsep dan Kemampuan Pemecahan Masalah Siswa SMA pada Materi Fluida Dinamis. Jurnal Penelitian \& Pengembangan Pendidikan Fisika, 01(1), 111-118. https://doi.org/10.21009/1.01116

Harks, B., Klieme, E., Hartig, J., \& Leiss, D. (2014). Separating Cognitive and Content Domains in Mathematical Competence. Educational Assessment, 19(4), 243-266. https://doi.org/10.1080/10627197.2014.964114

Harnett, J. (2012). Reducing discrepancies between teachers' espoused theories and theories-in-use: an action research model of reflective professional development. Educational Action Research, 20(3), 367-384. https://doi.org/10.1080/09650792.2012.697397

Hostos Community College. (2017). Center for Teaching and Learning (CTL): Hostos and Value Rubrics. Retrieved May 8, 2019, from http://www.hostos.cuny.edu/oaa/ctl_rubrics.htm

Hung, W. (2016). All PBL Starts Here: The Problem. Interdisciplinary Journal of Problem-Based Learning, 10(2). https://doi.org/10.7771/1541-5015.1604

Jaffe, L., Gibson, R., \& D’Amico, M. (2015). Process-Oriented Guided-Inquiry Learning: A Natural Fit for Occupational Therapy Education. Occupational Therapy in Health Care, 29(2), 115-125. https://doi.org/10.3109/07380577.2015.1010030

Jensen, J. L., Neeley, S., Hatch, J. B., \& Piorczynski, T. (2017). Learning Scientific Reasoning Skills May Be Key to Retention in Science, Technology, Engineering, and Mathematics. Journal of College Student Retention: Research, Theory \& Practice, 19(2), 126-144. https://doi.org/10.1177/1521025115611616

Kuhn, D., \& Pease, M. (2008). What Needs to Develop in the Development of Inquiry Skills? Cognition and Instruction, 26(4), 512-559. https://doi.org/10.1080/07370000802391745

Lawson, A. E. (2000). Classroom Test of Scientific Reasoning. Revised Edition Journal of Research in Science Teaching, 15(1), $11-24$.

Lee, C.-Q., \& She, H.-C. (2010). Facilitating Students' Conceptual Change and Scientific Reasoning Involving the Unit of Combustion. Research in Science Education, 40(4), 479-504. https://doi.org/10.1007/s11165-009-9130-4

Loyens, S. M. M., Jones, S. H., Mikkers, J., \& van Gog, T. (2015). Problem-Based Learning as a Facilitator of Conceptual Change. Learning and Instruction, 38, 34-42. https://doi.org/10.1016/j.learninstruc.2015.03.002

Magnani, L. (2002). Conjectures and manipulations: External representations in scientific reasoning. Mind \& Society, 3(1), 931. https://doi.org/10.1007/BF02511863

Martin, A. M., \& Hand, B. (2009). Factors Affecting the Implementation of Argument in the Elementary Science Classroom. A Longitudinal Case Study. Research in Science Education, 39(1), 17-38. https://doi.org/10.1007/s11165-007-9072-7

Mason, A., \& Singh, C. (2016). Using categorization of problems as an instructional tool to help introductory students learn physics. Physics Education, 51(2), 025009. https://doi.org/10.1088/0031-9120/51/2/025009 
Mustofa, M. H., \& Rusdiana, D. (2016). Profil Kemampuan Pemecahan Masalah Siswa pada Pembelajaran Gerak Lurus. Jurnal Penelitian \& Pengembangan Pendidikan Fisika, 02(2), 15-22. https://doi.org/10.21009/1.02203

Polya, G. (1973). How to Solve It A New Aspect of Mathematical Method (SECOND EDITION). New Jersev: Princeton University Press.

Pritasari, A. C., Dwiastuti, S., \& Probosari, R. M. (2016). Peningkatan Kemampuan Argumentasi melalui Penerapan Model Problem Based Learning pada Siswa Kelas X MIA 1 SMA Batik 2 Surakarta Tahun Pelajaran 2014/2015. Jurnal Pendidikan Biologi, 8(1), 1-7.

Raine, D., \& Symons, S. (2012). Problem-based learning: undergraduate physics by research. Contemporary Physics, 53(1), 39-51. https://doi.org/10.1080/00107514.2011.615162

Rees, C., Pardo, R., \& Parker, J. (2013). Steps to Opening Scientific Inquiry: Pre-Service Teachers' Practicum Experiences with a New Support Framework. Journal of Science Teacher Education, 24(3), 475-496. https://doi.org/10.1007/s10972012-9315-y

Rimadani, E., Parno, \& Diantoro, M. (2017). Identifikasi Kemampuan Penalaran Ilmiah Siswa Sma Pada Materi Suhu dan Kalor. Teori, Penelitian, dan Pengembangan, 2(6), 833-839.

Sahin, M. (2010). Effects of Problem-Based Learning on University Students' Epistemological Beliefs About Physics and Physics Learning and Conceptual Understanding of Newtonian Mechanics. Journal of Science Education and Technology, 19(3), 266-275. https://doi.org/10.1007/s10956-009-9198-7

Sambada, D. (2012). Peranan Kreativitas Siswa Terhadap Kemampuan Memecahkan Masalah Fisika Dalam Pembelajaran Kontekstual. Jurnal Penelitian Fisika dan Aplikasinya (JPFA), 2(2), 37. https://doi.org/10.26740/jpfa.v2n2.p37-47

Senocak, E., Taskesenligil, Y., \& Sozbilir, M. (2007). A Study on Teaching Gases to Prospective Primary Science Teachers Through Problem-Based Learning. Research in Science Education, 37(3), 279-290. https://doi.org/10.1007/s11165006-9026-5

Smart, J. B., \& Marshall, J. C. (2013). Interactions Between Classroom Discourse, Teacher Questioning, and Student Cognitive Engagement in Middle School Science. Journal of Science Teacher Education, 24(2), 249-267. https://doi.org/10.1007/s10972-012-9297-9

Sujarwanto, E., \& Hidayat, A. (2014). Kemampuan Pemecahan Masalah Fisika Pada Modeling Instruction Pada Siswa Sma Kelas XI. Jurnal Pendidikan IPA Indonesia, 14.

Tosun, C., \& Senocak, E. (2013). The Effects of Problem-Based Learning on Metacognitive Awareness and Attitudes toward Chemistry of Prospective Teachers with Different Academic Backgrounds. Australian Journal of Teacher Education, 38(3). https://doi.org/10.14221/ajte.2013v38n3.2

Tuminaro, J., \& Redish, E. F. (2007). Elements of a cognitive model of physics problem solving: Epistemic games. Physical Review Special Topics - Physics Education Research, 3(2). https://doi.org/10.1103/PhysRevSTPER.3.020101

Tytler, R., \& Peterson, S. (2005). A Longitudinal Study of Children's Developing Knowledge and Reasoning in Science. Research in Science Education, 35(1), 63-98. https://doi.org/10.1007/s11165-004-3434-1

Ulger, K. (2018). The Effect of Problem-Based Learning on the Creative Thinking and Critical Thinking Disposition of Students in Visual Arts Education. Interdisciplinary Journal of Problem-Based Learning, 12(1). https://doi.org/10.7771/1541-5015.1649

Vandenhouten, C., Groessl, J., \& Levintova, E. (2017). How Do You Use Problem-Based Learning to Improve Interdisciplinary Thinking?: How Do You Use Problem-Based Learning. New Directions for Teaching and Learning, 2017(151), 117133. https://doi.org/10.1002/t1.20252

Wijnia, L., Loyens, S. M. M., Derous, E., \& Schmidt, H. G. (2015). How Important are Student-Selected Versus InstructorSelected Literature Resources for Students' Learning and Motivation in Problem-Based Learning? Instructional Science, 43(1), 39-58. https://doi.org/10.1007/s11251-014-9325-6

Wu, Y., \& Tsai, C. (2011). High School Students' Informal Reasoning Regarding a Socio-Scientific Issue, with Relation to Scientific Epistemological Beliefs and Cognitive Structures. International Journal of Science Education, 33(3), 371400. https://doi.org/10.1080/09500690903505661

Wuriyudani, H. A., Wiyanto, W., \& Darsono, T. (2018). Problem Solving Heuristic to Develop Scientific Reasoning. Physics Communication, 3(1), 1-9. https://doi.org/10.15294/physcomm.v3i1.15022

Yadav, A., Subedi, D., Lundeberg, M. A., \& Bunting, C. F. (2011). Problem-based Learning: Influence on Students’ Learning in an Electrical Engineering Course. Journal of Engineering Education, 100(2), 253-280. https://doi.org/10.1002/j.2168-9830.2011.tb00013.x

Yew, E. H. J., Chng, E., \& Schmidt, H. G. (2011). Is learning in problem-based learning cumulative? Advances in Health Sciences Education, 16(4), 449-464. https://doi.org/10.1007/s10459-010-9267-y

Yew, E. H. J., \& Schmidt, H. G. (2012). What Students Learn in Problem-Based Learning: A Process Analysis. Instructional Science, 40(2), 371-395. https://doi.org/10.1007/s11251-011-9181-6 